\title{
TMT Cognition, First Mover Advantages and Firm Entreprenuerial Performance: A Review of Literature
}

\author{
Rahab W Ngugi ${ }^{1} \&$ James M. Kilika $^{2}$ \\ ${ }^{1}$ Doctoral Student, Department of Business Administration, School of Business, Kenyatta University, Kenya \\ ${ }^{2}$ Lecturer, Department of Business Administration, Kenyatta University, Kenya \\ Correspondence: James M. Kilika, Department of Business Administration, School of Business, Kenyatta \\ University. Kenya.
}

Received: April 17, 2018

doi:10.5539/ibr.v11n6p110

\author{
Accepted: May 9, 2018 \\ Online Published: May 18, 2018 \\ URL: https://doi.org/10.5539/ibr.v11n6p110
}

\begin{abstract}
Top Management Teams (TMT) cognition play a strategic role in the decision making process in any firm. It is critical for firms to integrate managerial strategic thinking, which is rooted in managerial cognition, into the strategic process. Hence TMT cognition can be seen to be a key intangible resource of the firm. The speed and efficiency of the firm's response to the rapidly changing environment is vital to firm performance. Firm's can integrate corporate entrepreneurship as a corporate strategy to achieve competitiveness in the market. This paper presents a review of extant theoretical and empirical literature on two constructs, TMT cognition and first mover advantages and their link to firm entrepreneurial performance. Relevant theories have been reviewed, constructs and operational indicators have also been identified, comparison against empirical studies and the emergent knowledge gap is identified. This paper proposes a theoretical model for guiding future scholarship in strategic management.
\end{abstract}

Keywords: top management teams cognition, first mover advantages, firm entrepreneurial performance

\section{Introduction}

Strategy is a process that is found at the organisation level, which includes activities that firms engage in in order to formulate and enact the strategic missions and goals ( (Li, Zhang, \& Chan, 2005) which involve analysing, planning, decision making and strategy implementation (Hart,1992). The fast-paced and rapid changing competitive environment of the firm brings both opportunities and threats for firms, and they have to interpret the opportunities and threats when making key strategic decisions (Dess, Lumpkin, \& Covin, 1997); Su, Xie, Wang, \& Li, 2011). Entrepreneurial strategy making (ESM), an end result of the opportunities and threats analysis will hence reflect the commitment of a firm to innovativeness, risk-taking and pro-activeness in the development and implementation of strategy, which is significant in the success of a firm (Shirokova, Bogatyreva, Beliaeva, \& Puffer, 2016); Su Xie Wang \&Li, 2011). The Top Management Teams (TMTs) are the principal decision makers in the development of the corporate strategy at the corporate level of strategy.

The construct of Top Management Teams (TMT) has been found to determine the speed, efficiency and effectiveness in the decision making process in organisations in a way that can influence firm performance. The effectiveness and nature of firm responses differ in part with the composition and characteristics of the top management teams (Neilsen, 2009). The managerial teams effects on firm performance has been a subject of interest to scholars in strategy (Neilsen, 2009; Michel \& Hambrick,1992). The Upper Echelon Theory (Hambrick \& Mason, 1984) identified and broadly clustered TMT characteristics into two categories: the observable characteristics of functional tracks, age, career experiences, financial position, socio-economic roots and group characteristics and the psychological characteristics such as cognitive base values.

Due to the nature of the external environment faced by organisations, strategic management emphasizes the role of adaptation in order to fit into the environment. The adaptability or strategic renewal stresses the important task of managerial cognition (Kaplan, 2011). Cognitive structures involving top management teams beliefs about the environment and strategy and also the cognitive process of scanning, sense making and interpretation is what is referred to as managerial cognition (Buyl, Boone, \& Paul, 2011). The behavioural theory of the firm (Cyert \& March, 1963), emphasizes the importance of the managerial cognitive process as an important characteristic of 
firm's strategic behaviour. The cognitive process represents the initial step in TMT-driven, deliberate change in the firm's strategy and behaviour (Tripsas \& Gavetti, 2002), raising the need to gain insight into the connection between the managerial composition and managerial cognition. Organization's adaptability normally is driven by TMT's cognitive process which is in turn driven by the TMT composition.

TMTs possess a cognitive framework that determines an organisations strategic choice as well as the timing of the execution of the strategic choice. The timing of the execution of strategic choice has seen scholars distinguish firms into two main categories: first movers and late movers. A first mover is a firm that identifies an opportunity in the environment and by acting first relative to the competitors is able to gain positive economic profits. First movers are also referred to as pioneers. First Mover Advantage (FMA) arises from three primary sources namely technological knowledge, pre-emption of assets and buyer switching cost. Technological leadership mechanism is either a learning curve advantage also known as experience curve and success in patent or research and development races. Learning curve advantage is achieved through unit production costs that falls with cumulative output, however this can only provide sustainable cost advantage for early entrants if kept proprietary and market share leadership is maintained (Lieberman \& Montgomery', 1987). For Technological advantage which is a function of experience achieved from research and development, pioneers can maintain it if it is patented or maintained as a trade secret. Firms can achieve advantages by pre-empting rivals in the acquisition of scarce assets that already exist rather than those developed by new technology. First mover advantages through buyer switching costs arise from initial transaction buyers make in adapting to the sellers products or services. Proponents of the FM construct have pointed that two factors will determine an organization's decisions on the timing of entry into the market: internal factors revolving around the state of resources (Lieberman \& Montgomery, 1998) and the industry clock speed (Fines, 1998)

The role of the TMT in this process has been associated with the nature of strategic management process that requires decision makers to analyse both the internal and external environment so as to bring out the set of opportunities and threats and identify the firms internal preparedness through resource capabilities. Various researchers have all agreed that firms operating in an environment that is rapidly changing need to embrace entrepreneurial activities in order to remain competitive. Companies can exploit the competitive advantages they own currently, while they at the same time make decisions to shape the advantages they have intentions to possess in future, increase probability of long-term survival, growth and financial success (Kuratko, Ireland, \& Hornsby, 2001). When firms base their entrepreneurial action on their strategy, then that firm is said to have a corporate entrepreneurship strategy. According to Kuratko, Ireland, and Hornsby (2001), in the 1980s to 1990s the virtual revolution of entrepreneurial actions were contributors to firm performance. Companies redefine the business, considering ways that most effectively use human resource and learning to compete in the global economy. This alters the firm's culture, infusing entrepreneurial spirit in their operations.

\subsection{Statement of the Problem}

The role of strategic management is to formulate and implement strategy at the corporate, business and functional levels. TMT's role in this process is very critical and hence the success or performance of the firm. TMT cognition is a relatively new area of interest in strategic management, especially with its focus on the role of making decisions at the corporate level. Building from studies conducted earlier, there seems to be conceptual, empirical and theoretical gaps when understanding the construct of TMT cognition, first mover advantages and firm entrepreneurial performance.

To further enhance the understanding of the distinction between pioneer and late entrants and the link to entrepreneurial performance, there is need to research more on the link between TMT cognition, external environment and strategic flexibility. Even though some studies provide some understanding on the difference in perception between early entrants and late entrants, they do not explain why an entrepreneur may chose to be a pioneer as opposed to a late entrant, or if the distinction matters. Fines(1998), Lieberman and Montgomery (1998) suggest that two sets of factors both within and without the firm are responsible for determining the timing of entry and raise implications for the conceptual modelling of the firm strategic behaviour that involves TM Cognition and strategic moves for attaining anticipated pioneer advantages. Various scholars (Amit \& Zott, 2001; Hitt \& Ireland, 2000; Hitt, Ireland, Camp \& Sexton, 2001, 2002) are in agreement that strategic management and entrepreneurship are two areas that are concerned with wealth creation in firms. Further the strategic role of TMT in decision making in the integration of entrepreneurship in strategy has not been clearly linked. There is need to propose a theory that integrates strategic management with entrepreneurship. This has emanated from empirical studies on firm entrepreneurial activities and firm performance. 
For this reason, this study will propose a theoretical framework to address this gap. This study will apply a multiplicity of theories in order to understand the constructs that underlie the phenomenon involving TMT Cognition, pioneer advantage and firm entrepreneurial performance in relevant contexts that typify those of interest in applying strategic management processes and concepts. The purpose of the study is to review the extant theoretical and empirical literatures with a view to identifying the linkage between the TMT cognition, first mover advantage and firm entrepreneurial performance. The study is guided by the following objectives: first, the study reviews extant theoretical and empirical literature on TMT cognition, first mover advantages and firm entrepreneurial performance. Secondly, the study reviews emerging theoretical and empirical gaps that form a basis for further research on TMT cognition, first mover advantage and firm entrepreneurial performance. Lastly, the study proposes a theoretical model responding to the theoretical and empirical gaps on TMT cognition, first mover advantage and firm entrepreneurial performance that can contribute to the body of knowledge by linking TMT cognition, first mover advantages and firm entrepreneurial performance.

In undertaking this study, the authors add to the extant literature in strategic management to enrich the current understanding of TMTs and the intermediate and ultimate outcomes of the decision making process in a strategic management context. In addition, in attempting to explore the nature of the constructs, the study applies a diversity of theories drawn from not only strategic management but also from Enterpreneurship theory and the behavioural sciences as we point at areas of complimentarity between the two disciplines of study, strategic management and Enterpreneurship. Lastly the study proposes a theoretical model that stands to guide future research in suggesting constructs, their operational indicators and proposed theoretical relationships that can be tested in empirical work.

\section{Review of Conceptual Literature}

As indicated in the objectives of the study, the paper is a presentation of summarized conceptual review on the constructs of TMT cognition, first mover advantage and firm entrepreneurial performance. Further a literature review of the same is conducted.

\subsection{The Construct TMT Cognition}

The construct of TMT cognition is a recent development in strategic management. It however seems to have its roots in some of the theoretical underpinnings of strategic thinking, traced from the work of Mintzberg, (1987). Mintzberg, (1987) used the concept of 5P's of strategy so as to capture the various dimensions of the concept of strategy. Considering the nature of the 5Ps, one is able to trace the origin of the construct of TMT cognition in this early work. The 5Ps are ; ploy, plan, position, pattern and perspective. To expound further, plan is a consciously intended course of action,, that is a deliberate strategy developed decisively and intentionally. Ploy is a specific manoeuvre intended to outwit a competitor. Pattern are the stream of actions taken by members of an organisation, consistency in behaviour, can be deliberate strategies or emergent strategies. Position is the place an organisation in positioned within the environment, strategy acts as mediator between the firm and the environment both internally and externally. And lastly, perspective is the ingrained way of perceiving the world. The last dimension of perspective as described by Mintzberg appears to lay the ground for the role of cognitions in the concept of strategy. As captured by Mintzberg, (1998), strategic planning would entail a systematic programming of pre-defined strategies from which an action plan is developed.

A model developed by Biggadike, (1981) used the concept of choice to place the construct of cognition in the heart of strategic thinking. According to the model, a firm's strategic choice is developed from the organisational capabilities, firm's environment and its current competitive position. And according to Lieberman and Montgomery, (1998) capabilities and resources have an influence on the entry timing as a strategic action. Extant literature argues that for any firm to successfully implement strategy, then there is need for strategic thinking to be incorporated. Strategic thinking is injected into the strategic management process at the early stages of the strategic planning process whereby strategy is developed from the continuous analysis of alternatives. However according to Liedkta's model, strategic thinking is an individual initiative where an individual can be influenced by the organisational context in which he operates (Graetz, 2002). While Bonn, (2001) argues that strategic thinking at individual level is composed of three main elements namely: holistic understanding of the organisation and its environment, degree of creativity, innovative solutions to issues that challenge existing approaches and thinking and lastly the vision of the future, inspiring and uniting people in the achievement of the corporate goals (O’Regan, Hughes, Collins, \& Tucker, 2010).

Nadkrani and Barr, (2008) in adressing the question on what drives strategic action offered an explanation based on two views: the managerial cognition view and industry structure view. Under the industry structure perspective, strategic decision makers are completely rational and contend that industry structure may impact on 
the effectiveness and timing of strategic actions Extant research on mangerial cogntion argues that different manager's perceive the same business environment differently (Nadkrani \& Barr, 2008; Gary \& Wood, 2010; Tripsas \& Gavetti, 2000). Bogner and Barr, (2000) and Walsh,(1995) in their research on managerial cognition and strategic action defined knowledge structure as a mental template where a person assumes the information available in the environment and finds meaning, the manager is provided with a basis that forms a biased representation of the environment that is used to inform the strategic action (Shepherd, MCullen, \& Ocasio, 2016). Recent studies in strategic action indicate that the intergration of managerial cogntion and industry structure leads to a better understanding of strategic action concept, (Johnson \& Hoopes, 2003). Buyl, Boone, and Paul, (2011) in defining TMT cognition, refer to the dimension of managerial cognition as TMT beliefs on environment and strategy and TMT cognitive processes.

Hurzschenreuter and Horstkotte, (2013), further in dissecting the aspect of cognition adopted the concept of faultline, which refers to a conceptual divide that seperates a managerial team into subgroups. They identified two types of faultlines, that is task-related faultlines and bio-demographic tenure. Task-related faultlines refer to the educational background and the length of organisational tenure while the bio-demographic faultines are the age and nationality differences. Task-related faultlines are hence based on characteristics that have been acquired which are indicators of knowledge and perspectives relevant to a particluar task. These dimensions assist managerial teams to successfully handle addition of new products in a given time period resulting in improved firm performance.

\subsection{First Mover Advantage}

The ultimate purpose of strategic management is to build sustainable competitive advantage in a firm. CEO's and TMT's role is to set direction for the firm by choosing the market the firm will participate and identify the resources it will nurture and deploy. For instance, product diversification can be used as a strategic action in a way that firms benefit by exploiting new market power among other benefits. However, it is worth noting that this move can have a strain on managerial resources, complexity on the task of management while addition of the product scope adds to the complexity. For a successful coordination of strategy, managers with experience and a deep knowledge of the firm as a bundle of resources is critical. The resource based view (RBV) has conceptualized the firm as a bundle of resources. The resources are managed and reconfigured by the managers who are motivated to exploit perceived market opportunities (Castanias \& Helfat,1991, 2001). The first mover advantages represent a critical concept in strategic management literature and in business practice (Carow, Heron, \& Saxton, 2004). Pioneer advantage implies that by acting earlier relative to peers, a pioneer can achieve a competitive advantage which enables a firm acquire economic profits (Lieberman \& Montgomery, 1988).

Pioneer advantages depend on information asymmetry concept, whereby a first mover capitalizes on superior information to recognize and respond upon some initiative to gain a head start over peer firms (Lieberman \& Montgomery', 1987). It can hence be argued that, TMT interpretation of the opportunities presented in the environment is key in first mover as a strategic choice. This is confirmed in Carow, Heron, and Saxton, (2004) paper on acquisitions, where an acquirer is able to process superior information which allows it to recognise and purchase an underpriced asset, that is, the acquirer knows more about the target's value before other investors, thus exploiting its information advantage.

Lieberman and Montgomery, (1998) article answered two questions that link FMA with RBV literature. First, the conditions under which an early entrant can enhance the organisations accumulation of superior resources and capabilities. Second, is whether capabilities and resources influence entry timing. Resources are the roganisational tangible and intangible assets, that iclude employee individual skills. Capabilities or competencies are organisation's collection for understaking a specific type of activity within the environment. Early entrants may be able to preempt resources ; superior geographical space, technological space, or customer perceptual space, blocking product space with a broadening product line, preemption of superior human resource . Pioneer entrants are able to define cost structures either through initial customer perception, accumulated positive customer experience that leads to switching costs and user influence through product perceived to be the industry standard. Early entrants can also develop organisational capabilities that are crucial to product or service such as manufacturing, marketing, which is also known as learning or experience curve advantage. Lieberman and Montgomery (1987)'s study showed that optimal timing of new entry into an new market depends on the resources and capabilities of an organisation whose strength is in the development of new products, while organisations whose strength is in marketing and manufacturing should enter as a late entrant. However, recent survey suggests that an organisation's resource base influences the options and entry timing. Market pioneers had significantly different skills than late entrants (Lieberman \& Montgomery, 1998). 
Potential early entrants usually examine potential opportunities by evaluating both perceived desirability and perceived feasibility (Zhao, Erekson, Wang, \& Song, 2012). These are conditioned by competencies developed from human capital, their evaluation and perception of market opportunities and self efficacy (Elfving et al., 2009; Mauer, Neergaard \& Lindstad, 2009). Zhao, Erekson, Wang, and Song, (2012) argue that performance and cost advantages influence perceived desirability of the entrepreneurial opportunities. The extent the advantages can be predicted is dependent on the clear lens through which potential pioneer examines market opportunities and capacity to apply specialised knowledge or resources to gain competitive advantage (Douglas, 2009).

Some firms are able to identify new niche markets through flexibility in exploitation and control of firm resources . Through competitive action, firms can develop and even protect their own competitive advantage. The competitiveness of their peers in the market can also be eroded by firm flexibility of resources (Nadkrani \& Narayanan, 2007). The constant configuration and rate of application on the competitive actions of a firm determines the capacity of the firm to change its competitive stand and in turn respond to competition efficiently (Young et al., 1996). Strategic schemas are the lenses through which strategic decision-makers interpret information and translate it into organizational actions. Strategic schemas influence firm performance by promoting effective strategic actions.

As mentioned earlier pioneer advantages occur in the dimensions of technological knowledge, pre-emption of assets and buyers switching (Lieberman \& Montgomery, 1987). First mover advantages through buyer switching costs arise from initial transaction buyers makes when adapting to a product or from the buyer who has supplier specific learning.

\subsection{Firm Entrepreneurial Performance}

Firms tend to seek ways to continue growth and one of the principle mechanism is entrepreneurial activities. According to Penrose (1959), entrepreneurship is a contributor and consequence of growth in firms. There is a need for firms to reconfigure new and old resources in order to gain more value. Through adaptive capabilities, firms can expand the entrepreneurial activities to take advantage of presented opportunities. The relationship between firm growth and firm entrepreneurial behaviour, firm growth and managerial perception towards risk is mediated by adaptive capability. Adaptive capability is a firm's adeptness of market expectations. Augmented understanding and corresponding exposure to new entrepreneurial opportunities is the central antecedent to tangible entrepreneurial activities undertaken to capture opportunities. Consequences of entrepreneurial orientation or activities is firm growth, knowledge generation, strategic learning and improvement of strategic positioning.

Extant literature argues that entrepreneurship is concerned with growth strategies while strategic management is concerned with creation of wealth (Amit \& Zott,2001; Hitt \& Ireland, 2000; Hitt, Ireland, Camo \& Sexton, 2001, 2002; Zahra, 2008). Entrepreneurship's main objective is growth and wealth creation (Ireland, Kuratko \& Covin, 2003). Entrepreneurship is viewed as a motivator of economic growth through actions of individual firms, especially in emerging, developing and developed economies (Peng, 2001, Zahra, Ireland, Gutierrez \& Hitt, 2000). Entrepreneurship and strategic management can be seen to be two disciplines that are complementary (Ireland, Hitt, \& Sirmon, 2003). A firm that exploits entrepreneurial opportunities as its strategy not only contributes to its effort to form sustainable competitive advantage but also in wealth creation. However firms must motivate and encourage their employees to be innovative and creative through providing the right internal environment. However entrepreneurs risk failing to develop sustainable competitive advantage, this is as a result of failure of entrepreneurs to strategically manage resources. (Hitt, Ireland, Camp, et al., 2001). Therefore for sustainable wealth creation, both entrepreneurship, which is opportunity-seeking and strategic management that is advantage seeking, must complement each other (Amit \& Zott, 2001; Hitt \& Ireland, 2000; Mcgrath \& MacMillan, 2000). According to Penrose, (1959), entrepreneurship is a contributor and consequences of growth.

Whereas in strategic management performance has been mostly operationalised through objective indicators of profits. That however leaves out the important dimensions on sustainability of the profit which can benefit from the perspective drawn from entrepreneurship. Entrepreneurship is interested in sustainability, growth and ability to continue to earn profits. This is an agreement with the view advanced by proponents to the construct of sustainable competitive advantage that leads towards acquired capability for a firm to be able to contionously earn or post satisfactory returns. The perspective from entrepreneurship studies has a better inclination which stands to provide a more clear path for organisations employing entrepreneurship based strategic innovation with the hope of sustaining performance in the long term. There is therefore need for scholarship from both streams to build consensus in understanding the construct of entrepreneurial performance. Chirico, (2006b) study on family business defined entrepreneurial performance as a new and innovative form of competitve advantage achieved 
through entrepreneurial innovation and strategic adaptation to the market.

\subsection{Issues Arising from the Conceptual Review}

The reviewed conceptual literature has pointed to a number of issues. First is the emerging implication of the possibility of a phenomenon that describes firm strategic behaviour in terms of a diversity of constructs involving TMT Cognition, Pioneer advantage and firm performance. From this emerging pehnomenon, it is notable that TMTs play a role in strategic decisions that have implications for pioneer advantages, there is also an implied link between TMT cognition, the external environment and strategic flexibility that may explain dinstinctions among first movers and late entrants. The outcome of this strategic flexibility leads to actions that are entrepreneurial in nature as firms respond to market opportunities. This offers scholars a lens by which linkages between TMT cognition and firm entrepreneurial moves may be seen.

Secondly, a review of several empirical attempts reveals the different ways the constructs have been operationalised and applied in empirical work. For example Gary and Wood, (2011) looked at the accuracy of mental models at an individual level, indicating that the variations in mental models is key in performance. Hurzschenreuter and Horstkotte, (2013) used observable characteristics of the UET to measure psychological characteristics. Zhao,Erekson,Wang and Song,(2012); Zhao and Parry,(2012) looked at perception on pioneer advantages and disadvantages and the effects of first mover of entrepreneurs. Su, Xie,Wang and $\mathrm{Li}$, (2011) examined the entrepreneurial strategy making, resources and firm perfromance. Carow, Heron and Saxton, (2014) study operationalised information asymmetry when making first mover decisions.

Thirdly, there is an emerging issue on the conceptualization of constructs as well as their operationalization. Notable in this are two constructs, performance and TMT Cognition. Whereas in strategic management performance has been mostly operationalised through objective indicators of profits, that perspective however leaves out the important dimensions on sustainability of the profit which can benefit from the perspective drawn from entrepreneurship. Entrepreneurship is interested in sustainability, growth and ability to earn profits which in our view tends to close the gaps in conceptualization between proponents of sustainable competitive advantage on the one hand and those in enterpreneurship supporting the view advanced by proponents to the construct of sustainable competitive advantage that leans towards acquired capability for a firm to be able to continously earn or post satisfactory returns. The perspective from entrepreneurship studies has a better inclination which stands to provide a more clear path for organisations employing entrepreneurship based strategic innovation with the hope of sustaining performance in the long term. There is therefore need for scholarship from both streams to build consensus in understanding the construct of entrepreneurial performance. Towards this then, the authors consider the limitations of the perspective by the approach adopted by Chirico (2006b) and the state of the extant literature and offer an alternative description to the construct of enterpreneural performance. Thus the authors add their voice to the extant literature their perspective to the construct of enterpreneural peroformance and define it as "the outcome of an enterpreneural oriented organization's strategic efforts that offer potential for sustainability of the firm through dimensions such as growth, ability to earn profits and overall viability."

Fourthly, the review of the literature points at a gap in understanding the role of the determinants of the timing of entry to achieve pioneer advantages in the phenomenon that derives from TMT Cognition in making strategic moves that should realize this advantage as suggested by Fines (1998) and Lieberman and Montgomery (1998). On the one hand, Lieberman and Montgomery, (1998) point that when a firm is deliberating on the decision of entry timing, the optimal timing will depend on the strengths and weaknesses of the firm's existing resource base and its capabilities and competencies, while on the other Fines (1998) basing his argument in managerial consideration of industry clock speed indicated that the clock speed influences a firm's strategic flexibility. The clock speed comprises product, process and organisational attributes. Product clock speed is the firm's consideration of new product introduction and the obsolescence rate. Process clock speed reflects on the rate of change and replacement of technological processes within an industry. While organisational attributes is the rate of change at the strategic actions and structures, strategic flexibility is the ability of organisations to expedite intentional changes, in response to the environmental change. The authors are of the view that since these two determinants have not been considered in extant research, an attempt should be made to suggest how they may be modelled to explain the phenomenon involving TMT Cognition and pioneer advantage.

Lastly, given the diversity of issues that have been raised, the authors are of the view that there is need for application of multiplicity of theories that underpin constructs describing the phenomenon that involves TMT's Cognition, pioneer advantages and firm entrepreneurial performance. Considering the theoretical underpinnings offers an opportunity to anchor both the constructs and the phenomenon on sound theoretical ground as the phenomenon needs clear understanding for empirical application. 


\subsection{Review of Relevant Theories}

The previous discussion on concepts has comprehensively discussed the nature of the constructs emanating from TMT cognition, first mover advantages and emerging entrepreneurial firm performance. This debate raises issues that call for an assessment of the appropriate theories that can explain this phenomenon. To further advance the TMT cognition construct, this paper has taken a multi disciplinary approach by adopting theory from behavioural science that could prove valuable in extending the needed explanation of the behaviour of the phenomenon. The paper considers postulates and contributions of the: Upper Echelon theory, Theory of Administrative Behaviour, Managerial Cognitive Theory, Resource based view of the firm, The Game Theory and Theory of Entrepreneurial Orientation

\subsubsection{The Upper Echelon Theory}

The Upper Echelon Theory (UET) argues that the demographic characteristics and background of top management team members have an influence on the strategic decisions of the organisations, which have a direct impact on the performance and value creation in the organisation (Hambrick \& Mason1984). In their paper, they proposed a model that explains how the managers characteristics could influence the strategic choice in organisations. More emphasis was on the observable characteristics, as indicators of the value managers bring to the firm. These characteristics includes age, functional background, tenure in the organisation, education, socio economic roots and financial position. The study on background characteristics was further emphasised and reaffirmed by other researches in other fields like marketing who study on demographic as an indicators of consumer preference. At this point upper level manager's cognitive bases, values and perceptions were not convenient to measure. Another proposal that was developed from the study is that scrutiny of the upper management team was more effective than on individual managers.

Hambrick, (2007) introduced two refinements as important moderators, these are managerial discretion and excutive job demands. Discretion exists in the absence of constraint and when there are multiple feasible alternatives. Hence, when there is presence of discretion, managerial characterritics are reflected in strategy and performance. Development of executive job demands is derived from task challenges, strategic conditions that are difficult for managers and challenges from performance that include owners or board members who can be demanding as well as aspirations from the excutive who are pushed to perform. Faced with challenges such as intense jobs, executives will normally apply what has worked in past for them, the strategic choice will be a reflection of their background and dispositions (Hambrick, Finkelstein, \& Mooney, 2005).

Further two additional refinements were added to the theory. Intra-TMT power distribution which argues that some TMT's have more say than others, hence their biases is highly dependable when predicting managerial actions (Hambrick, 2007). Hambick on the other hand introduced TMT behaviarol integration. The degree to which a TMT engages in mutual and collective interaction is known as behavioral integration, which has a direct positive effect on organisational performance. Thus TMTs need to engage collectively in information processing or decision making. (Hambrick, 2007). The theory is linked to TMT cognition in that it reveals demographic characteristics of TMT members influence on strategic decision making..

\subsubsection{Managerial Cognitive Theory}

Managerial cognitive theory is rooted in Piaget theory of cognitive development, is a comprehensive theory that addresses the nature and development of human intelligence and later the development of the cognitive theory which explains the mental processes, influenced by both intrinsic and extrinsic factors. This theory explains how different processes that involve learning can be explained by analysing the mental processes. Cognition is the mental action or process of acquiring knowledge and understanding through experience and senses. According to Stimpert,( 1999) review, managerial cognition theory is concerned with the development of a deep understanding of the way in which managers think. Managerial cognition emphasises on the upper echelon theory objective of positioning the manager at the center stage (Eden \& Spender, 1998). The issues on the importance of the managers and the organisation in making sense of situations and events. Sense making involves the intepretation, frames, schemas and assumptions of situations or events (Meindl, Stubbart, \& Porac, 1994).

\subsubsection{Theory of Administrative Behaviour of the Firm}

The theory of Administrative Behaviour of the firm (AB) was introduced by Simon, (1997) who presented the manager as an administrative man who uses decision premises. The decision premises explain: how the organisation can be understood by their decision process ; decision premises influences behaviour, behaviour can also modify decision premises; individual decision premises can be influenced by structures or objectives of the organisation, and as a result, the decisions undertaken are in line with the objectives of the organisation. 
Jemison,(1986) classified the contribution into three categories: study of the organisation in the context of the environment ; study of managerial action in the context of an organisation ; and lastly the development of techniques to improve strategies alignment with organisation capabilities and its environment. The aforementioned postulates reveal the link of this theory to TMT cognition.

Organisations are seen as open systems that must have support and feedback from their environment. Hence they are systems that interact with greater systems (enviroments) and engage in life sustaining processes of exchange. The responsibility of deciding which product to produce or the service to deliver, internal rationalisation or throughtput procedure to implement, allocation of resources in order to achieve throughput that can compensate on the value recieved from external constituences is within the strategies. When considering the managerial actions in context of the environment, the $\mathrm{AB}$ theory seeks to undesrtand what the manager actually does through activities such as entrepreneurial decision making, allocating resources, operating decisions (Chandler, 1962). This theory is linked to TMT cognition, where managerial decisions are in agreement with the organisations structures, objectives and environment.

\subsubsection{Resource Based View Theory of the Firm}

The resource based view is a theory that explains a way the firm can be viewed and the strategic choices available. The RBV theory emphasizes the use of firm resources and internal capabilities in strategy formulation to enable a firm acquire sustainable competitive advantage in the market and industry. The proponent of RBV theory, Penrose (1959), emphasized the need to view the firm as a bundle of resources. Thus, growth of firms is both facilitated and limited by managerial teams search for the optimum use of available resources. The theory is also linked to Prahalad and Hamel (1990), Rumelt, Schendel, \& Teece, (1991), who examined the differences in firm profitability within and across the specific industry. Resources comprise of capabilities, process attributes, assets, knowledge that is owned by a firm, which can be used for the formulation and implementation of competitive strategies. Prahalad and Hamel essentially conceptualized the firm as a bundle of resources, the difference between firms is seen through the difference in combination of the resources in order to deliver products or services. If an organisation is viewed as made of capabilities and resources, which can be configured and re-configured to provide a competitive advantage, then the internal capabilities determine the strategic choices it makes in competing in its external environment.

Prior research on RBV basically investigated the association among available resources and performance, but this has now evolved and resources are said to possess certain characteristics, that is, resources are valuable, rare, inimitable and non-substitutable. These characteristics allow organisations to plan better in implementing strategic actions. When the activities taken by the firm emphasize on economic use of the resources, competitive advantage is created which can then translate to enhanced performance (Ketchen-JR, Hultz, \& Slater, 2007). The RBV theory hence provides a theoretical backing to FMA which lacks in the concept. The theory is also linked to TMT cognition in that TMT cognition is an intangible resource and capability that has an impact of the re-configuration of other resources.

\subsubsection{Game Theory}

The proponents of Game theory, Zermelo and Neumann introduced this concept as a branch in mathematics that is concerned with the analysis of strategies to deal with competitive situations where the outcome of the participants depends on the other participants (Bonanno, 2015). The theory is divided into two branches, cooperative game theory and non-cooperative. In the cooperative game theory players are assumed they can communicate, form coalitions and sign binding agreements. While the non-cooperative theory, players are in a situation where they are unable to communicate, with no possibility of signing a binding contract. Game theory has also been defined as part of a greater body of theory that provides a formal language to describe cognisant, goal-oriented, decision making process that involves one or more players (Shubik,1972). It can also be as an analysis of logical activities in situations that involve interdependence of results (Camerer, 1991). Game theory models two or more players, in this case firms, who have a variety of activities on alternatives of choices or strategies, while they have specific information that guides. Every firm has preferred varied results, with the outcomes of interaction that depends on decisions of all the players (Ogot). The choice of which strategies to implement determines the consequences which yield pay-offs (Camerer, 1991). The reasoning in game theory is a decision rule or algorithm that selects an equilibrium strategy, firms discover an equilibria by introspection. Introspection is a mental or computational process simulating outcomes of various choices, eliminating choices that do not yield expected outcomes or reconfiguring the choices. According to research by Chau, (1996), game theory goes beyond the classic theory of probability, strategic aspects are emphasized or controlled by the participants, hence the adoption in the study of competiton, where there are several factors for instance 
conflicting intrests, incomplete information, chance and interplay of rational decisions. The goal is to utilize the game rules to forecast the equilibrium outcome of the game in terms of maximisation of profits and improvement of market price influctuations, which may threaten the sustainability of the firm, producers who are faced with the risk of market prices (Sahin, Yildirim, \& Miran, 2009). This theory is connected to the concept of first mover advantage when firms are addressing the critical questions on how payoffs can be achieved from the strategic decision made to attain competitive advantage.

\subsubsection{Theory of Entrepreneurial Orientation}

In a rapidly changing environment, for a firm to continuously remain competitive, considering the resources and capabilities that have been developed over time, TMT's need to have an entrepreneurial mindset that will recognise opportunities that present themselves. Integration of entrepreneurship in strategic process will eventually change the firm's culture- this encourages an innovative and creative environment and allocation of resources for entrepreneurial activities. As organisations grow, they gain new resources and the business environment changes, hence need to mix existing and new resources in value creating ways. Firms can exploit new opportunities through the expansion of entrepreneurial activities through adaptive capabilities. EO leads to firm's growth, knowledge generation, strategic learning and an improvement of strategic positioning (Eshima \& Anderson, 2016). The concept of entrepreneurial orientation looks at strategic process and the styles of firms that engage in entrepreneurial activities (Covin \& Slevin,1998; Lumpkin \& Dess,1996; Wiklund \& Shepherd, 2003). Covin and Slevin, (1988) defined a firm's entrepreneurial orientation in terms of the extent managers and strategist are inclined to take business-related risks, favour change and innovation and compete aggressively with other firms.

The five components of EO are innovativeness, risk-taking, pro-activeness, autonomy and competitive aggressiveness. Risk-taking describes the act of managers allocating finances to activities or project that have uncertain results. Pro-activeness is whereby a firm is able to engage in entrepreneurial activities to predict opportunities in future, both from a perspective of technologies or products and consumer and market demand. Innovativeness is the consideration on the product variations and services to be introduced in the market, while emphasizing the importance of leadership in technology as well as product line. Competitive aggressiveness is the way an organisation engages with competition, differentiate among firms that do not embrace competition directly with those that have a direct approach. Autonomy is the autonomous way of introducing ideas or visions implementing it to completion (Lumpkin \& Dess,1996) while not hampered by company's inflexibilities. (Schillo, 2011). This theory reveals that an integration of EO in the strategy of a firm will improve its performance.

\subsubsection{Issues Rising From the Theoretical Review}

The review of theories has brought out the theoretical anchorage of the constructs of TMT's, FMA and firm entrepreneurial performance. For example the Upper Echelon Theory, managerial cognitve theory and theory of administrative behaviour of the firm explain the role of TMT's in complex situations where they rely on their background, past interactions and the desire for performance. The organisation structures, objectives, understanding of the environment, use of decision premises to influence their cognitive ability when making decision making. The FMA construct has been identified in the RBV theory and game theory. The reasons behind the choice to be a pioneer can be explained by the game theory. The firm entrepreneurial performance construct has been identified in the entrepreneurial orientation theory.

From the review, the theories are complimentary to each other. For example TMT cognition can be explained through the upper echelon theory that introduced the psychological characteristics which are influenced by the observable characteritics. The psychological characteristics are rooted in the managerial cognitive theory. The role of TMT's can be examined using the theory of adminstrative behaviour of the firm . TMT cognition as a firm resource and hence the resource based view theory of the firm. The pioneering strategic choice of the firm can be explained by the game theory, while firm entrepreneurship which is also a resource within the firmis explained by the entrepreneurial orientation theory.

Several empirical studies have used the theories to examine the constructs of this study, and in some cases other constructs beyond this study. Hurzschenreuter and Horstkotte, (2013), used the Upper Echelon Theory to measure managerial and growth related characteristics to analyse firm performance. Nadkrani and Narayanan, (2007) examined the Upper Echelon Theory to investigate the linkage among industry clockspeed, strategic schemas and strategic action of performance. Lieberman and Montgomery, (1998) journal reviews linked empirical findings on first mover and RBV. Zhao and Parry, (2012) study on the impact of perceived pioneer advantages, in consensus with prior work by Lieberman and Montgomery pioneer advantages. Various 
researchers such as Doorn, Jansen, Bosch, and Volberda, (2013); Zhao and Parry, (2012) ; Zahra,( 2008) all examined the EO theory to underpin their studies. Kantur, (2016) study that focused on developing a clearer understanding of the relationship between firm level entrepreneurship and firm performance in an emerging economy, argued that EO leads to increased performance through strategic entrepreneurship.

Lastly, in our review,we also find that from the RBV, there are close links between the two disciplines of strategic management and entrepreneurship in terms of their focus on prosperity of organisations. The outcome of strategic entrepreneurial moves that take the form of performance have not also been adequately addressed in the theory and empirical attempts in strategic management. Finally the construct of TMT cognition can be viewed as one of the key capabilities of the firm that is vital in influencing key decisions of the firm. This is an important observation that scholarship in strategic management needs to pickup and build on to strengthen links between theories focusing on TMT and those that focus on firm resources.

\section{The Call for a Theoretical Model}

The review of the conceptual, empirical and theoretical literatures has brought out a number of issues that make a case for a proposal of a new theoretical model involving the constructs of TMT Cognition, first mover advantage and enterpreneurial performance. First, is the emergence of a phenomenon linking TMT cognition, first mover and firm entrepreneurial performance calling for efforts to model linkages among the constructs. Secondly, the emerging phenomenon involves more contigent factors touching on entrepreneurial orientation and industry clockspeed as a determinant of timing of entry into the market whose role in the phenomenon needs to be ascertained. Thirdly, the review raises the need for a multidiscplinary based approach for modelling the relationships among the constructs as well as their operationalized indicators in describing the emerging phenomenon and the strategic behavior in organizations. Lastly, there is need for a scientifically relevant approach to the advancement of knowledge in management using these constructs so as to inform the direction furture research needs to take. The scientific methodology towards advancement of knowledge based on both ontological and epistemological inclinations supports the view that advancement of new knowledge calls for theoretical models (theories) that affirm empirical work. There are debates as to whether theory should come before research or vice versa (Nachmias \& Nachmias, 2004). Proponents of the school of thought supporting theory before research base their argument on the fact that a theoretical framework supports a research study theory by Constructing an explicit theory or model, Selecting a proposition derived from the theory and modelling for empirical investigation and Designing a research project to test propositions. This allows the researcher to examine assumptions, address queries of why and how, permit the researcher to intellectually progress from simply describing phenomenon that has been observed to generalising various aspects of the phenomeono and assist in identifying limits to those generalization (Wandiga, Kilika, \& James, 2017 ; Nachmias \& Nachmias, 2004). Thus in consideration of the above observations, the authors are of the view that there is a compelling case for the development of a new model to relate TMT cognition with firm entrepreneurial performance as conditioned by several contextual factors.

\subsection{The Proposed Theoretical Framework}

From the reviewed literature several constructs emerged from both the theoretical and conceptual literature. These constructs include TMT cognition, firm entrepreneurial performance, pioneer advantage, entrepreneurial orientation and industry clock speed. The role of a theory is developed to clarify, envisage and comprehend phenomenon and in several situations test and expound existing knowledge within the limits of critical bounding assumptions. Therefore in order to progress knowledge in a conventional manner, the authors propose the following theory designating different roles in a phenomenon that involves the above five constructs. The model presents a phenomenon whose antecedent factor is the TMT cognition. TMT cognition has two dimensions : mental processes and task related fault lines. The intermediate state emerging from the TMT cognition is the first mover advantage. According to literature the advantage results from technological knowledge, pre-emption of scarce resources and buyer switching costs. The ultimate state is that of firm entrepreneurial performance. This construct has been operationalized through indicators of customer satisfaction, sustainable competitive advantage, sustainable profits and growth. The contingent factors include entrepreneurial orientation and the industry clock speed. 


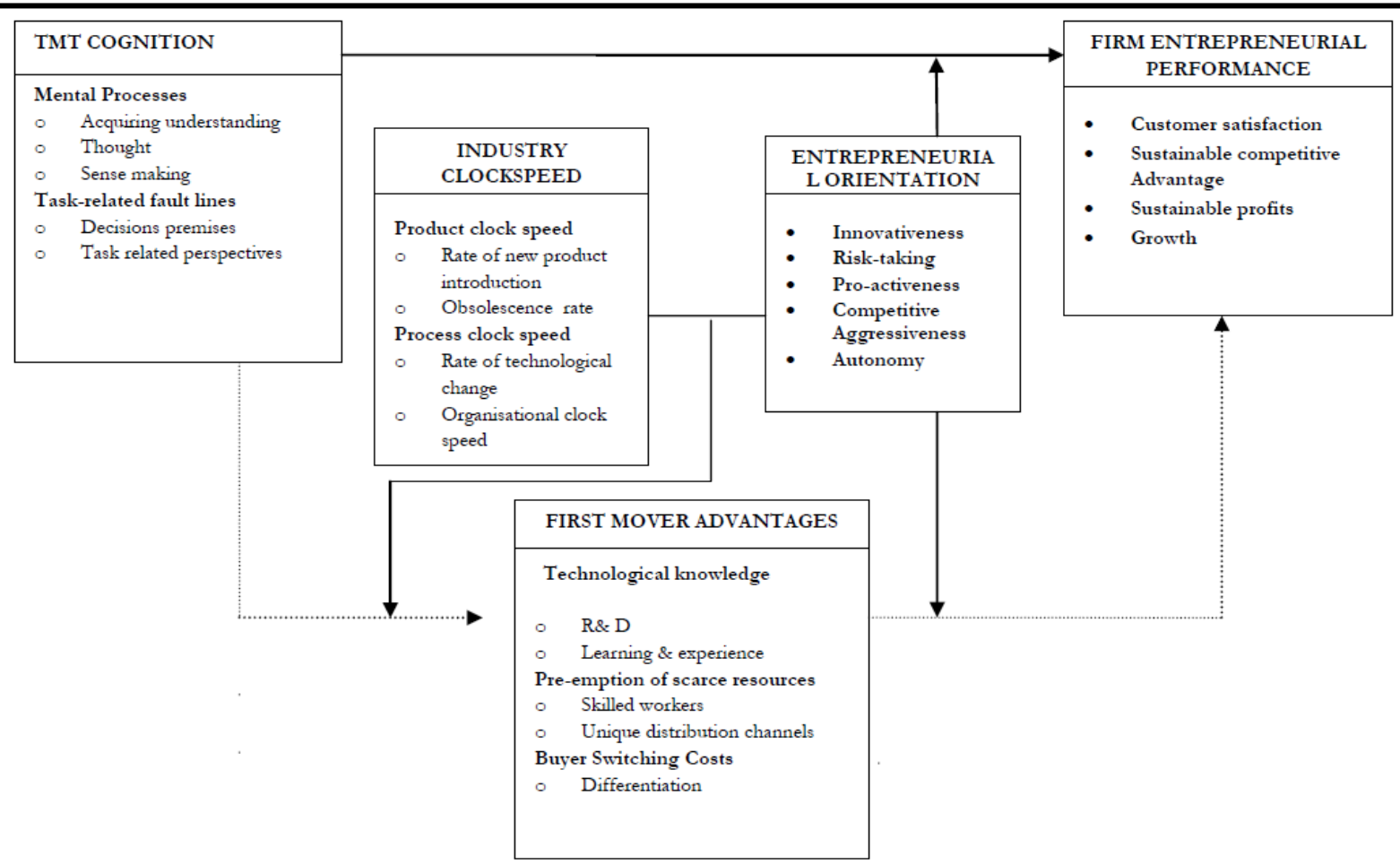

Figure 1. Theoretical Model showing the relationship between TMT Cognition and Entrepreneurial Performance

\subsection{Propositions}

\subsubsection{TMT Cognition and Firm Entrepreneurial Performance}

Strategy formulation and implementation is normally undertaken at three levels in a firm, the corporate level, business level and functional level. Corporate level strategy is the level at which TMT's are the primary decision makers. TMTs provide the overall managerial game plan for a company to achieve its objectives and stakeholders expectations. TMTs are faced with complex situations calling for the adaptability or strategic renewal that emphasizes the role of managerial cognition (Kaplan, 2011) in strategic choice. According to Neilsen, (2009), the nature and effectiveness of firm's response to changing environmental conditions vary due to the characteristics and compositions of TMTs. TMT's cognitive ability to identify opportunities within the environment that optimize achievement of organizational goals will be crucial. It is expected that well constituted TMT's will take time to understand their external contexts, make sense of the key requirements of the external context and generate appropriate decision premises that appropriately respond to the demands of the external environment. The responsiveness to the environment through the quality of decisions made by the TMT members will bring about outcomes that correspond to the requirements of the market. Cognitions are key to the relevance of the responses TMTs generate for response to their environments as they reflect how well TMTs perceive, interpret and attach meaning to vital environmental cues that require strategic response. The cues require the systems in the organization to be aligned in a manner that they are innovative enough to generate the required responses. The responses that are considered sufficiently innovative will bring about results that will enhance the entrepreneurial performance of an organization such that the firm generates profits on a continual basis, the firm competes effectively and the market is satisfied. Thus, the paper proposes that:

Proposition One: TMT Cognition in strategically oriented firms has influence on the firm's Entrepreneurial Performance.

\subsection{The Role of First Mover Advantage}

TMT strategic responses that are innovative in nature targeting to enhance entrepreneurial performance of firms will emphasize sensitivity to timing of the launch of the strategic Responses. The speed at which a firm responds to its changing external environment is key to attaining the desired firm entrepreneurial performance. As firms deliberate on the decision of entry timing, the optimal timing will depend on the strengths and weaknesses of the 
firm, existing resource base and its capabilities and competencies (Lieberman \& Montgomery, 1998). Thus, it is argued in this paper that TMTs in firms that intend to build and sustain desirable levels of entrepreneurial performance will need to build the needed capability and competence for purposes of sustaining this performance so that the firm can be a pioneer in making strategic moves in the market and not only earn this perceived position of a pioneer but also enjoy the pioneer advantages that derive from pre-emption, buyers switching costs and technical knowledge. The concept of first mover advantage assumes a firm can recognize and respond promptly first upon some identified opportunity in the business environment. In view of this logic, the paper proposes that:

Proposition Two: TMT Cognition in strategically oriented firms will lead the firms to make strategic moves that earn the firms First Mover Advantages as a necessary condition for sustaining their desired Entrepreneurial Performance level.

Proposition Three: The earned state of First Mover Advantage will determine the strength of the relationship between the strategically oriented firm's TMT Cognition and the desired level of Entrepreneurial Performance.

\subsection{Role of Enterpreneurial Orientation and Industry Clock speed}

It has already been suggested that TMT Cognitions need to generate strategic responses that from the viewpoint of the market are sufficiently innovative. Thus, the paper argues that in terms of strategic thinking, two factors from within and without the firm will be critical in determining the level of performance attained, namely the firm's enterpreneural orientation and the industry clock speed. Innovation as a defining attribute of the firm needs to be supported by a culture that demonstrates attributes of enterpreneural orientaion in terms of innovativeness, Risk-taking behaviour, Pro-activeness, and Competitive Aggressiveness. If these attributes are prevalent as components of the culture of the firm, both employees and systems will work towards initiatives that generate appropriate innovations that adequately respond to the conditions faced in the market so as to realize outcomes that promote the firms entrepreneurial standing on a continual basis. Secondly, since the strategic responses that register such entrepreneurial performance outcomes are considered as strategic choices, such choices are subject to the dictates of the conditions of the industry in which the firm operates. Thus the industry clock speed in terms of Product, process clock speed and the Rate of new product introduction will influence the firm's strategic flexibility that will determine how fast the firm can initiate strategic moves. Considering the findings of previous empirical work by Meyer et.al (2009), Kilika (2012), and Kilika et.al (2013) that identified complimentarity between RBV and environmentally based approaches to organizational studies of Resource dependence and institutional theories, it is observed that the industry clock speed will play a contingent role in the phenomenon linking the TMT Cognition and the earned capability of first mover advantage. Entrepreneurial Orientation as an aspect of the internal culture prevailing in the organization will be critical as a contingent factor not only in the path from TMT Cognition to firm entrepreneurial performance but also the indirect path from TMT Cognition to First Mover Advantage and that of first mover advantage to firm entrepreneurial performance. Thus, informed by this logic, the paper proposes that:

Proposition Four: The relationship between the strategically oriented firm's TMT Cognition and the earned capability of First Mover Advantage will be conditioned by the combined effect of the state of Industry Clock speed for the firm and the firm's Entrepreneurial Orientation.

Proposition Five: The strategically oriented firm's entrepreneurial orientation will condition both the relationship between the firm's TMT Cognition and its desired Entrepreneurial Performance as well as that between the earned level of First Mover Advantage and the desired firm Entrepreneurial Performance.

\section{Conclusion and Direction For Further Research}

The purpose of this paper was to review the extant literature on the construct of TMT cognition, First Mover Advantage and enterpreneural performance. The study reviewed both conceptual and empirical literature that provided different perspectives to the understanding of the constructs as well as their operational indicators. The relevant theories upon which the constructs are anchored reviewed included the Upper Echelon theory, Managerial cognitive theory and Administrative behaviour of firms which introduced the construct of TMT cognition. First mover advantage concept has been anchored on the Theory of Resource Based View of the firm and Game Theory. The emerging gaps identified from the types of literature reviewed were used to propose a theoretical framework showing the different conceptual roles the constructs play in the phenomenon that involves TMT Cognition, FMA, Enterpreneural perfromance, enterpreneural orientation and industry clock speed. The paper presented several propositions that highlight the direct and conditional links among the variables. 
The discussions advanced in this paper leading to the proposed theoretical framework and the propositions make several contributions to the continuing discourse in strategic management. First, the paper had identified the need for an enhanced understanding of the constructs of TMT Cognition, First mover advantage and firm entrepreneurial performance. The study relied on multiple perspectives drawn from extant conceptual literature underpinned in an integrated multidisciplinary theoretical base drawn from managerial cognitive theory which is rooted in psychology, Theory of Administrative Behaviour drawn from the behavioural science, Game theory drawn from Mathematics and Theory of Entrepreneurial Orientation which is borrowed from Entrepreneurship. From these, the constructs were described, their conceptual nature, characteristics and operational indicators identified. In addition, using previous research work, the authors expanded the scope of the current understanding of the construct of entrepreneurial performance and provided an alternative definition to that offered earlier by Chirico (2006).

Secondly, the research aimed at addressing the various linkages between the TMT cognition, external environment and strategic flexibility for the purpose of demonstrating the possibility of an emerging phenomenon involving the constructs. Besides the attempt made towards operationalization of the constructs, the study further identified the emerging strategic management phenomenon as well as designation of the roles that each would serve in the phenomenon. While TMT Cognition serves as the antecedent factor, strategic flexibility and the environment serve as contingent factors through entrepreneurial orientation and industry clock speed respectively. Finally, the study proposed a new theoretical model with a clear set of constructs and operational indicators that can guide future research. The theoretical framework proposed can be practically tested in different sectors of the economy where innovation and creativity provide a platform for competitiveness.

While this paper contributes to literature on strategic management, more specifically TMT cognition and firm perfomance, it also proposes further research on other attributes of TMT cognition that have either not been researched such as task related fautlines and their contribution to TMT cognition and decision making. The paper has also taken a multidiscplinary approach, proposing further research on entrepreneurial orientation and industry clockspeed and how these concepts can be integrated with the discpline of entreprenuership to come up with a theoretical conclusion. Since the propositions made face a limitiation in that they have not yet been empirically tested, the authors propose that future research be undertaken in relevant contextual settings to assess how the constructs proposed and the emergent phenomenon empirically behaves. Such attempts will require researchers to develop approapriate data collection tools using the operationalized indicators and apply relevant statistical techniques to test the relationships. Some industries where such initiatives may be applied include firms in information and communication technology, agribusiness, manufacturing .

\section{References}

Amit, R., \& Zott, C. (2001). Value creation in E-business. Strategic Management Journal, 22(6-7), 493-520. https://doi.org/10.1002/smj.187

Biggadike, E. R. (1981). The Contributions of Marketing To Strategic Management. Academy of Management Review, 6(4), 621-632. https://doi.org/10.5465/amr.1981.4285710

Bogner, W. C., \& Barr, P. S. (2000). Making Sense in Hypercompetitive Environments: A Cognitive Explanation for the Persistence of High Velocity Competition. Organization Science, 11(2), 212-226. https://doi.org/10.1287/orsc.11.2.212.12511

Bonanno, G. (2015). Game Theory :An open access textbook with 165 solved exercises. University of California, Davis.

Bonn, I. (2001). Developing strategic thinking as a core competency. Management Decision, 39(1), 63-71. https://doi.org/10.1108/eum0000000005408

Buyl, T., Boone, C., \& Matthyssens, P. (2011). Upper echelons research and managerial cognition. Strategic Organization, 9(3), 240-246. https://doi.org/10.1177/1476127011417345

Camerer, C. F. (1991). Does strategy research need game theory? Strategic Management Journal, 12(S2), 137-152. https://doi.org/10.1002/smj.4250121010

Carow, K., Heron, R., \& Saxton, T. (2004). Do early birds get the returns? An empirical investigation of early-mover advantages in acquisitions. Strategic Management Journal, 25(6), 563-585. https://doi.org/10.1002/smj.404

Castanias, R. P., \& Helfat, C. E. (2001). The managerial rents model: Theory and empirical analysis. Journal of Management, 27(6), 661-678. https://doi.org/10.1177/014920630102700604 
Certo, S. T., Covin, J. G., Daily, C. M., \& Dalton, D. R. (2001). Wealth and the effects of founder management among IPO-stage new ventures. Strategic Management Journal, 22(6-7), 641-658. https://doi.org/10.1002/smj.182

Chandler, A. D. (1962). Strategy and structure. Cambridge:MIT Press.

Chau, C. (1996). Game theory and strategic auditing: part I - introduction. Managerial Auditing Journal, 11(4), 21-25. https://doi.org/10.1108/02686909610120000

Chirico, F. (2006b). Knowledge, Dynamic Capabilities and Family Inertia in Family Firms: A Computational Approach. Electronic Journal of Family Business Studies (EJFBS), 1(2), 2007.

Covin, J.G. \& Slevin, D.P. (1998). The influence of organization structure on the utility of an entrepreneurial top management style. Journal of Management Studies, 25(3), 217-234.

https://doi.org/10.1111/j.1467-6486.1988.tb00033.x

Cyert, R. M., \& March, J. A. (1963). A Behavioural Theory of the Firm. Englewood Cliffs

Dess, G., Lumpkin, G., \& Covin, J. (1997). Entrepreneurial Strategy Making and Firm Performance: Tests of Contingency and Configurational Models. Strategic Management Journal, 18(9), 677-695. https://doi.org/10.1002/(sici)1097-0266(199710)18:9\%3C677::aid-smj905\%3E3.0.co;2-q

Elfving, J., Brännback, M., \& Carsrud, A. (2009). Toward a contextual model of entrepreneurial intentions. In Understanding the entrepreneurial mind: Opening the black box, ed. A. L. Carsrud and M. Brännback, 23-34. Dordrecht: Springer. https://doi.org/10.1007/978-1-4419-0443-0_2

Eshima, Y., \& Anderson, B. S. (2016). Firm growth, adaptive capability, and entrepreneurial orientation. Strategic Management Journal, 38(3), 770-779. https://doi.org/10.1002/smj.2532

Fines, C. H. (1998). Clockspeed: Winning Industry Controlling the Age of Temporary Advantage.

Frankfort-Nachmias, C., \& Nachmias, D. (2004). Research Methods in the Social Sciences (5th ed.).

Gallén, T. (2009). Top management team composition and views of viable strategies. Team Performance Management: An International Journal, 15(7/8), 326-342. https://doi.org/10.1108/13527590911002113

Gary, M. S., \& Wood, R. E. (2010). Mental models, decision rules, and performance heterogeneity. Strategic Management Journal, 32(6), 569-594. https://doi.org/10.1002/smj.899

Graetz, F. (2002). Strategic thinking versus strategic planning: towards understanding the complementarities. Management Decision, 40(5), 456-462. https://doi.org/10.1108/00251740210430434

Hambrick, D. C. (2007). Upper Echelons Theory: An Update. Academy of Management Review, 32(2), 334-343. https://doi.org/10.5465/amr.2007.24345254

Hambrick, D. C., \& Mason, P. A. (1984) Upper Echelons: The Organization as a Reflection. Academy of Management Review, 9(2), 193-206. https://doi.org/10.5465/amr.1984.4277628

Hambrick, D. C., Finkelstein, S., \& Mooney, A. (2005). Executive job demands: New insights for explaining strategic decisions and leader behaviors. Academy of Management Review, 30(3). https://doi.org/10.5465/amr.2005.17293355

Hart, S. L. (1992). An integrative framework for strategy- making processes. Academy of Management Review, 17(2), 327-351. https://doi.org/10.5465/amr.1992.4279547

Hitt, M. A., \& Ireland, R. D. (2000). The intersection of entrepreneurship and strategic management research. Blackwell Publishers Ltd.

Hitt, M. A., Ireland, R. D., Camp, S. M., \& Sexton, D. L. (2001). Strategic entrepreneurship: entrepreneurial strategies for wealth creation. Strategic Management Journal, 22(6-7). https://doi.org/10.1002/smj.196

Hutzschenreuter, T., \& Horstkotte, J. (2012). Performance effects of top management team demographic faultlines in the process of product diversification. Strategic Management Journal, 34(6), 704-726. https://doi.org/10.1002/smj.2035

Ireland, R. D., Hitt, M. A., \& Sirmon, D. G. (2003). A Model of Strategic Entrepreneurship: The Construct and its Dimensions. Journal of Management, 29(6), 963-989. https://doi.org/10.1016/s0149-2063_03_00086-2

Ireland, R. D., Kuratko, D. F., \& Covin, J. G. (2003). Antecedents, Elements, and Consequences of Corporate Entrepreneurship Strategy. Academy of Management Proceedings, 2003(1), L1-L6. https://doi.org/10.5465/ambpp.2003.13793054 
Jemison, D. B. (1986). Disciplines that have contribution to Administrative Behaviour to strategic Management.

Johnson, D. R., \& Hoopes, D. G. (2003). Managerial cognition, sunk costs, and the evolution of industry structure. Strategic Management Journal, 24(10), 1057-1068. https://doi.org/10.1002/smj.320

Kantur, D. (2016). Strategic entrepreneurship: mediating the entrepreneurial orientation-performance link. Management Decision, 54(1), 24-4324-43. https://doi.org/10.1108/md-11-2014-0660

Kaplan, S. (2011). Research in Cognition and Strategy: Reflections on Two Decades of Progress and a Look to the Future. Journal of Management Studies, 48(3), 665-695. https://doi.org/10.1111/j.1467-6486.2010.00983.x

Ketchen, D. J., Hult, G. T. M., \& Slater, S. F. (2007). Toward greater understanding of market orientation and the resource-based view. Strategic Management Journal, 28(9), 961-964. https://doi.org/10.1002/smj.620

Kilika, J. M. (2012). Institutional context, collaboration, human resource development infrastructure and performance of universities in Kenya. Unpublished Ph. D Thesis. School of Business, University of Nairobi.

Kilika, J. M., K’Obonyo, P. O., Ogutu, M., \& Munyoki, J. M. (2013). Human Resource Development Drivers for University-Industry Collaboration: Empirical Evidence from Universities in Kenya. International Journal of Education and Research, 1(4), April. http//www.ijern.com/April-2013.php

Kuratko, D. F., Ireland, R. D., \& Hornsby, J. S. (2001). Improving Firm Performance Through Entrepreneurial actions: Acordia Corporate Entrepreneurship Strategy. Academy of Management Executive, 15(4), 60-71. https://doi.org/10.5465/ame.2001.5897658

Sexton, L., \& Landstrom, H. (Eds.), Handbook of entrepreneurship, 45-63. Oxford: Blackwell Publishers.

Li, H., Zhang, Y., \& Chan, T. S. (2005). Entrepreneurial strategy making and performance in China's new technology ventures - the contingency effect of environments and firm competences. Journal of High Technology Management Research, 16(1), 37-57. https://doi.org/10.1016/j.hitech.2005.06.003

Lieberman, M. B., \& Montgomery, D. B. (1998). First Mover (Dis)Advantages: Retrospective and Link with the Resource-Based View. Strategic Management Journal, 19(12), 1111-1125. https://doi.org/10.1002/(sici)1097-0266(1998120)19:12\%3C1111::aid-smj21\%3E3.3.co;2-n

Lieberman, M. B., \& Montgomery', D. B. (1987). First Mover Advantages. Strategic Management Journal, 9 , 41-58. https://doi.org/10.1002/smj.4250090706

Lumpkin, G. T., \& Dess, G. G. (1996). Clarifying the Entrepreneurial Orientation Construct and Linking It to Performance. The Academy of Management Review, 21(1). https://doi.org/10.2307/258632

Mauer, R., Neergaard, H., \& Linstad, A. K. (2009). Self-efficacy: Conditioning the entrepreneurial mindset. In Understanding the entrepreneurial mind, 233-257. https://doi.org/10.1007/978-1-4419-0443-0_11

McGrath, R. M., \& MacMillan, I. C. (2000). The entrepreneurial mindset. Boston: Harvard Business School Press.

Meindl, J. R., Stubbart, C., \& Porac, J. F. (1994). Cognition Within and Between Organizations: Five Key Questions. Organization Science, 5(3). https://doi.org/10.1287/orsc.5.3.289

Meyer, K. E., Estrin, S., Bhaumik, S. K., \& Peng, M. W. (2009). Institutions, resources, and entry strategies in emerging economies. Strategic management journal, 30(1), 61-80. https://doi.org/10.1002/smj.720

Michel, J. G., \& Hambrick, D. C. (1992). Diversification posture and top management team characteristics. Academy of Management Journal, 35(1) 9-37. https://doi.org/10.2307/256471

N. Wandiga, E., Kilika, J. M., \& James, R. (2017). Firm Performance in the Context of Knowledge Based Intensive Sector: A Theoretical Review. International Journal of Business and Management, 12(8), 234. https://doi.org/10.5539/ijbm.v12n8p234

Nadkarni, S., \& Barr, P. S. (2008). Environmental context, managerial cognition, and strategic action: an integrated view. Strategic Management Journal, 29(13), 1395-1427. https://doi.org/10.1002/smj.717

Nadkarni, S., \& Narayanan, V. K. (2007). Strategic schemas, strategic flexibility, and firm performance: the moderating role of industry clockspeed. Strategic Management Journal, 28(3), 243-270. https://doi.org/10.1002/smj.576

Nielsen, S. (2009). Why do top management teams look the way they do? A multilevel exploration of the 
antecedents of TMT heterogeneity. Strategic Organization, 7(3), 277-305. https://doi.org/10.1177/1476127009340496

O’Regan, N., Hughes, T., Collins, L., \& Tucker, J. (2010). Strategic thinking in family businesses. Strategic Change, 19(1-2), 57-76. https://doi.org/10.1002/jsc.858

Ogot, M. M. (n.d.). Game Theory in Strategic Management. University of Nairobi Enterprises and Services in Ltd.

Peng, M. W. (2001). How entrepreneurs create wealth in transition economies. Academy of Management Executive, 15(1), 95-108. https://doi.org/10.5465/ame.2001.4251397

Penrose, E. T. (1959). The theory of the growth of the firm. New York: John Wiley \& Sons.

Porter, M. E. (1985). Competitive Advantage. New York: Free Press.

Prahalad, C. K., \& Hamel, G. (1990). The core competence of the organization. Harvard Business Review, 68(May-June), 79-91. https://doi.org/10.1016/B978-0-7506-7223-8.50003-4

Rumelt, R. P., Schendel, D., \& Teece, D. J. (1991). Strategic management and economics. Strategic Management Journal, 12(S2), 5-29. https://doi.org/10.1002/smj.4250121003

Şahin, A., Yıldırım, İ., \& Miran, B. (2009). Developing strategies for chicken meat producers against market prices risks in Turkey (Game Theory approach). British Food Journal, 111(9), 975-987. https://doi.org/10.1108/00070700910992871

Schillo, S. (2011). Entrepreneurial Orientation and Company Performance: Can the Academic Literature Guide Managers? pp. 20-25. http://timreview.ca/article/497

Shepherd, D. A., MCullen, J. S., \& Ocasio, W. (2016). Is that an Opportunity? An attention model of Top Model of Top Managers' Opportunity Beliefs for Strategic Action , Strategic Management Journal, 38(3), 624-644. https://doi.org/10.1002/smj.2499

Shirokova, G., Bogatyreva, K., Beliaeva, T., \& Puffer, S. (2016). Entrepreneurial orientation and firm performance in different environmental settings. Journal of Small Business and Enterprise Development, 23(3), 703-727. https://doi.org/10.1108/jsbed-09-2015-0132

Simon, H. A. (1997). Administrative Behaviour: 4th Edition. Free Press.

Stimpert, J. L., Eden, C., \& Spender, J. C. (1999). Managerial and Organizational Cognition: Theory, Methods and Research. The Academy of Management Review, 24(2), 360. https://doi.org/10.2307/259088

Su, Z., Xie, E., Wang, D., \& Li, Y. (2009). Entrepreneurial strategy making, resources, and firm performance: evidence from China. Small Business Economics, 36(2), 235-247. https://doi.org/10.1007/s11187-009-9211-9

Tripsas, M., \& Gavetti, G. (2000). Capabilities, Cognition, and Inertia: Evidence from Digital Imaging, Strategic Management Journal, 21(1011), 1147-1161. https://doi.org/10.1002/1097-0266(200010/11)21:10/11\%3C1147::aid-smj128\%3E3.3.co;2-i

Van Doorn, S., Jansen, J. J. P., Van den Bosch, F. A. J., \& Volberda, H. W. (2013). Entrepreneurial Orientation and Firm Performance: Drawing Attention to the Senior Team. Journal of Product Innovation Management, 30(5), 821-836. https://doi.org/10.1111/jpim.12032

Walsh, J. P. (1995). Managerial and Organizational Cognition: Notes from a Trip Down Memory Lane. Organization Science, 6(3), 280-321. 1. https://doi.org/10.1287/orsc.6.3.280

Young, G., Smith, K. G., \& Grimm, C. M. (1996). "Austrian” and Industrial Organization Perspectives on Firm-level Competitive Activity and Performance. Organization Science, 7(3), 243-250. https://doi.org/10.1287/orsc.7.3.243

Zahra, S. A. (2008). Being entrepreneurial and market driven: implications for company performance. Journal of Strategy and Management, 1(2), 125-142. https://doi.org/10.1108/17554250810926339

Zahra, S. A., Ireland, R. D., Gutierrez, I., \& Hitt, M. A. (2000). Privatization and Entrepreneurial Transformation: Emerging Issues and a Future Research Agenda. The Academy of Management Review, 25(3), 509. https://doi.org/10.2307/259307

Zhao, Y. L., \& Parry, M. E. (2012). Mental Models and Successful First-mover Entry Decisions: Empirical Evidence from Chinese Entrepreneurs. Journal of Product Innovation Management, 29(4), 590-607. 
https://doi.org/10.1111/j.1540-5885.2012.00927.x

Zhao, Y. L., Erekson, O. H., Wang, T., \& Song, M. (2012). Pioneering Advantages and Entrepreneurs' First-mover Decisions: An Empirical Investigation for the United States and China. Journal of Product Innovation Management, 29, 190-210. https://doi.org/10.1111/j.1540-5885.2012.00963.x

\section{Copyrights}

Copyright for this article is retained by the author(s), with first publication rights granted to the journal.

This is an open-access article distributed under the terms and conditions of the Creative Commons Attribution license (http://creativecommons.org/licenses/by/4.0/). 